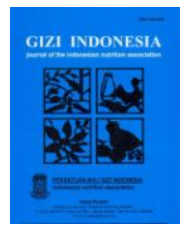

http://ejournal.persagi.org/ojspersagi2481/index.php/Gizi_Indon

\title{
KUALITAS DIET, SOSIO-DEMOGRAFI, DAN DUKUNGAN KELUARGA HUBUNGANNYA DENGAN PENGENDALIAN GULA DARAH PADA PENDERITA DIABETES MELITUS TIPE 2 DI RUMAH SAKIT KANUJOSO DJATIWIBOWO (RSKD), BALIKPAPAN
}

\author{
Association of Diet Quality, Sosio-demography and Family Support and Blood Glucose Control in Type \\ 2 Diabetes Mellitus Patient in Kanujoso Djatiwibowo Hospital, Balikpapan
}

Praseptia Gardiarini ${ }^{1}$, Totok Sudargo ${ }^{2}$, I Dewa Putu Pramantara ${ }^{3}$

${ }_{1}^{1}$ Politeknik Kemenkes Balikpapan, Jl. Soekarno-Hatta km 8, Balikpapan

${ }^{2}$ Magister Gizi Kesehatan, Fakultas Kedokteran UGM, JI. Farmako Sekip Utara, Yogyakarta

${ }^{3}$ Bagian Penyakit Dalam RSUP Dr. Sarjito, Jl. Kesehatan, Yogyakarta

E-mail: tiagardiarini@gmail.com

\section{ABSTRACT}

Diet Quality is an important factor to control blood glucose and it could avoid the patient of Type 2 Diabetes Mellitus (T2DM) from complication. Socio-demography factors and family support could impact management of T2DM. The ojective of the study to know the relationship of diet quality, sociodemography factors, and family support to control blood glucose in patient with T2DM at Kanujoso Djatiwibowo Hospital. A cross-sectional study was used in this study to know the relationship of diet quality, socio-demography factors, and family support to control blood glucose. Diet Quality IndexInternational (DQI-I) was used to assess diet quality of all subjects. Hensarling Diabetes Family Support Scale (HDFSS) questionnaire was used to know about family support. Data were analyzed using path regression to know the relationship of diet quality, socio-demography factors, and family support to $\mathrm{HbA1c}$. The result showed that all subjects had score of diet quality approximately $55.97 \pm 6.1$. Income and education level factors had significant relationship with diet quality, i.e. 6.55 percent and 7.11 percent $(p<0.05)$. There was inverse relationship between family support and $\mathrm{HbA1c}$ level. Income and education level factors have affect on diet quality. No correlation found between diet quality, socio-demography factors and family support with $\mathrm{HbA} 1 \mathrm{c}$ level.

Keywords: Diet Quality Index-International (DQI-I), family support, Type 2 Diabetes Mellitus (T2DM)

\section{ABSTRAK}

Pengendalian gula darah yang buruk, dapat memperparah terjadinya penyakit. Kualitas diet merupakan faktor penting dalam pengendalian gula darah. Pengendalian gula darah yang baik dapat menghindarkan penderita diabetes melitus (DM) dari kemungkinan komplikasi lebih lanjut. Kualitas diet, sosio-demografi dan dukungan keluarga akan berdampak terhadap manajemen penyakit DM, hubungan diantara ketiga hal tersebut belum pernah diteliti sebelumnya. Penelitian ini bertujuan untuk mengetahui kaitan kualitas diet, faktor sosio-demografi dan dukungan keluarga dengan pemeliharaan gula darah pada pasien DM Tipe 2 di Rumah Sakit Kanujoso Djatiwibowo (RSKD), Balikpapan. Studi cross-sectional digunakan untuk mengetahui kaitan antara kualitas diet, faktor sosio-demografi dan dukungan keluarga terhadap pengendalian gula darah. Diet Quality Index-International (DQI-I) digunakan untuk menilai kualitas diet, kuesioner Hensarling Diabetes Family Support Scale (HDFSS) digunakan untuk mengetahui dukungan keluarga. Path regression digunakan untuk mengetahui pengaruh kualitas diet, sosio-demografi dan dukungan keluarga terhadap HbA1c. Hasil penelitian menunjukkan, skor kualitas diet subjek penelitian mencapai rata-rata $55,97 \pm 6,1$. Pendapatan dan pendidikan memiliki pengaruh signifikan pada kualitas diet, yaitu 6,6 dan 7,1 persen $(p<0,05)$. Tidak ditemui hubungan yang signifikan antara pendidikan dan pendapatan dengan kualitas diet pada kadar HbA1c. Kesimpulan penelitian ini, pendidikan dan pendapatan memiliki pengaruh pada skor kualitas diet. Tidak ditemukan hubungan yang signifikan antara kualitas diet, faktor sosio-demografi dan dukungan keluarga dengan kadar HbA1c.

Kata kunci: DQI-I, dukungan keluarga, DM tipe 2 


\section{PENDAHULUAN}

$\mathrm{D}$ iabetes melitus (DM) merupakan penyakit metabolis yang berlangsung kronis dan progresif, dengan ciri meningkatnya konsentrasi gula dalam darah, yang dapat mengakibatkan komplikasi penyakit lain yang lebih serius. ${ }^{1}$ DM dibedakan menjadi dua, yakni DM tipe 1 dan tipe 2. Jumlah penderita DM tipe 2 mengalami peningkatan secara perlahan setiap tahun; diperkirakan 439 juta orang di dunia akan terdiagnosis DM tipe 2 pada tahun 2030.2 Tahun 2030 prevalensi penderita DM di Indonesia diprediksi akan mencapai 21,3 juta orang. Hasil Riset Kesehatan Dasar (Riskesdas) tahun 2007 menunjukkan, proporsi penyebab kematian akibat DM pada kelompok umur 45-54 tahun menduduki peringkat ke-2 di perkotaan $(14,7 \%)$ dan ke-6 di perdesaan $(5,8 \%){ }^{2}$

Diet memegang peran penting dalam tata laksana penyakit DM Tipe 2. Kualitas diet penderita DM bergantung pada jenis dan ukuran makanan yang dikonsumsi selama satu hari. Untuk mengetahui kualitas diet telah dikembangkan beberapa instrumen pengukuran kualitas diet. Salah satu dari empat instrumen yang digunakan di Asia adalah Diet Quality Index International (DQI-I). DQI-I menilai empat aspek dalam kualitas diet meliputi variasi (variation), kecukupan (adequacy), ukuran (moderation) dan keseimbangan keseluruhan (overall balance). ${ }^{3}$

Sosio-demografi merupakan faktor penting yang perlu diperhatikan dalam penentuan kebijakan kesehatan. Penelitian yang dilakukan di North City Iran menunjukkan bahwa ada pengaruh sosio-demografi terhadap prevalensi DM. ${ }^{4}$ Penelitian di Indonesia mengenai sosiodemografi dilakukan dengan menggunakan data Riskesdas 2007. Prevalensi DM banyak ditemukan pada sampel yang memiliki pendidikan kurang $(56,4 \%)$. Penelitian ini juga mengaitkan faktor sosio-demografi dengan kontrol gula darah. ${ }^{5}$

Dukungan keluarga sebagai salah satu sumber dukungan sosial merupakan suatu sikap, tindakan, dan penerimaan keluarga terhadap penderita yang sakit. Keluarga berfungsi sebagai sistem pendukung bagi anggotanya. ${ }^{6}$ Penelitian yang dilakukan Kim dan Yun pada pasien DM di Korea mendapatkan hasil yang signifikan pada dukungan keluarga kaitannya dengan pengendalian gula darah pada penderita DM Tipe $2(p<0,01) .{ }^{7}$ Penelitian ini bertujuan untuk mengetahui korelasi antara kualitas diet, faktor sosio-demografi dan dukungan keluarga terhadap manajemen pemeliharaan gula darah pasien DM tipe 2.

\section{METODE PENELITIAN}

Penelitian ini merupakan penelitian observasional dengan rancangan penelitian cross-sectional. Penelitian dilaksanakan di Rumah Sakit Kanujoso Djatiwibowo (RSKD) Balikpapan. Pengambilan data dilaksanakan bulan November 2013 sampai Januari 2014. Penghitungan besar sampel menggunakan proporsi pada studi survei analitis. ${ }^{8}$ Dari perhitungan tersebut didapatkan jumlah sampel sebanyak 85 subjek. Subjek merupakan pasien pengunjung ke Poli Interna RSKD dengan diagnosis DM tipe 2; memiliki data pemeriksaan gula darah jangka panjang $(\mathrm{HbA} 1 \mathrm{c})$ satu kali selama 3 bulan terakhir; laki-laki dan perempuan berusia >20 tahun; memiliki anggota keluarga yang tinggal serumah dengan pasien (suami/istri/ayah/ibu/mertua/anak/ saudara kandung); dapat berkomunikasi dengan baik, tidak mengalami komplikasi akut saat penelitian berlangsung (berdasarkan diagnosis dokter yang terdapat pada catatan medis pasien), dan tidak sedang hamil. Pengambilan sampel dilakukan dengan consecutive purposive sampling. Proses pengambilan sampel ini dilakukan dengan cara semua subjek yang datang dan memenuhi kriteria pemilihan dimasukkan dalam penelitian sampai jumlah subjek yang diperlukan terpenuhi. Analisis data digunakan dengan regresi jalur (path regression) untuk mengetahui pengaruh pada setiap variabel eksogenus terhadap variabel endogenus. Istilah variabel yang digunakan pada analisis jalur ada tiga macam, yaitu variabel eksogenus, endogenus, dan variabel luar/residu. Variabel residu adalah variabel yang secara teoretis memiliki hubungan, tetapi dalam penelitian ini tidak dimasukkan ke dalam analisis. ${ }^{9}$ Variabel residu dalam penelitian ini mencakup umur, status gizi, aktivitas fisik dan edukasi gizi.

Variabel luar yang dimasukkan ke dalam profil sampel meliputi usia yang didapatkan dari 
pengisian kuesioner; status gizi didapatkan melalui pengukuran antropometri berat badan dan tinggi badan dengan pengategorian Indeks Massa Tubuh (IMT) $\leq 18,5$ (kurus); IMT =18,522,9; (normal); IMT = 23,0-24,9 (overweight) IMT = 25-29,9 (obese I); IMT $\geq 30$ (obese II). ${ }^{10}$ Aktivitas fisik diperoleh dari pengisian kuesioner International Physical Activity Questionnaire (IPAQ) modifikasi dari penelitian Syam untuk mengetahui data aktivitas fisik, kemudian data yang telah diperoleh dihitung dengan mengalilipatkan durasi aktivitas fisik dalam menit dengan konversi yang telah ditetapkan oleh IPAQ dengan kategori perhitungan Metabolic Equivalent (MET), yakni: skor <600 METmenit/minggu (aktivitas ringan); skor $\geq 600 \mathrm{MET}$ menit/minggu sampai dengan $<1500$ METmenit/minggu (aktivitas sedang); skor $\geq 1500$ MET-menit/minggu (aktivitas berat). ${ }^{11}$ Data diolah dengan menggunakan software Microsoft Excel. Edukasi gizi diperoleh dari pengisian kuesioner.

Variabel bebas/eksogen yang digunakan dalam penelitian ini adalah kualitas diet yang dinilai dari 4 aspek meliputi variasi (variation), kecukupan (adequacy), ukuran (moderation) dan keseimbangan keseluruhan (overall balance) dengan skor total berkisar 0-100 poin. Kategori 'kurang' bila skor 0-45, kategori 'cukup' jika skor 55-60, dan kategori 'baik' bila skor lebih dari $70 .{ }^{3}$ Sosio-demografi yang mencakup umur, jenis kelamin, jumlah anggota keluarga, status perkawinan, pendidikan dan pendapatan, diperoleh melalui pengisian kuesioner. Dukungan keluarga diperoleh dengan menggunakan kuesioner modifikasi yang diadaptasi dari kuesioner Hensarling Diabetes Family Support Scale (HDFSS); terdiri dari empat dimensi yang dinilai antara lain dimensi emosional, dimensi informasi, dimensi penghargaan dan dimensi intrumental. Terdapat 29 pernyataan dengan penggunaan skala Likert untuk menghitung skor dukungan keluarga dengan kategori 'selalu mendapat dukungan keluarga' (rata-rata skor $=4$ ); 'sering mendapat dukungan keluarga' (rata-rata skor $=3$ ); 'jarang mendapat dukungan keluarga' (rata-rata skor = 2); 'tidak pernah mendapat dukungan keluarga' (rata-rata skor $=1) .8 \quad$ Variabel terikat/endogen adalah kadar HbA1c. Data $\mathrm{HbA} 1 \mathrm{c}$ menggunakan data sekunder, yaitu data pemeriksaan yang ada pada rekam medis satu kali selama tiga bulan terakhir terhitung sejak penelitian berlangsung. $\mathrm{HbA} 1 \mathrm{c}$ dikatakan terkontrol baik bila kadarnya $\leq 6,5$. Path regression digunakan untuk mengetahui hubungan antar-variabel.

\section{HASIL}

Subjek penelitian ini terdiri dari 85 orang dan 63 persen dari subjek adalah perempuan. Sebagian besar subjek berusia 55-64 tahun $(49,4 \%)$ dan berstatus menikah $(74,3 \%)$. Sebanyak 27 subjek $(31,8 \%)$ menempuh pendidikan selama 6 tahun dan terdapat 2 subjek yang tidak bersekolah. Subjek terbanyak berprofesi sebagai ibu rumah-tangga $(49,4 \%)$. Aktivitas fisik dibedakan menjadi tiga penilaian berdasarkan IPAQ 2005; subjek penelitian yang paling banyak adalah yang memiliki aktivitas 600-1500 MET-menit/minggu (aktivitas sedang), yakni sebesar 49,4 persen. Hanya 11,8 persen yang memiliki aktivitas lebih dari 1500 METmenit/minggu (aktivitas berat), selebihnya masuk dalam kategori aktivitas rendah (Tabel 1). Subjek terbanyak adalah pasien DM dengan lama menderita sakit sekitar 5-15 tahun $(49,4 \%)$, dengan metode pengobatan yang dijalani berupa pengobatan dengan obat oral $(63,5 \%)$ dan belum mengalami komplikasi $(37,7 \%)$. Subjek yang paling banyak adalah subjek yang mendapatkan edukasi gizi DM sekali selama menderita DM $(75,3 \%)$ (Tabel 2).

Pengukuran antropometri berat dan tinggi badan yang dilakukan pada subjek menunjukkan bahwa status gizi subjek penelitian yang paling banyak adalah normal, sedangkan $\mathrm{HbA} 1 \mathrm{C}$ sebesar 87 persen adalah $\geq 6,5$ persen yang mengindikasikan bahwa kebanyakan pasien memiliki profil gula darah yang kurang terkendali. Rata-rata skor kualitas diet subjek penelitian adalah $55,97 \pm 6,1$. Ratarata skor komponen variasi adalah 15,82 $\pm 2,04$, untuk komponen kecukupan mencapai rata-rata skor 23,91 $\pm 3,77$, sedangkan skor untuk variabel ukuran rata-rata mencapai 13,90 $\pm 2,57$ dan skor untuk komponen keseimbangan keseluruhan rata-rata mencapai 2,32 $\pm 2,17$ (Tabel 3). Ratarata skor dukungan keluarga yang dihasilkan dari pengukuran pada subjek penelitian mencapai 2,52, dengan nilai dukungan keluarga terendah adalah 1,46 dan nilai dukungan keluarga tertinggi adalah 3,36 (Tabel 4). 
Tabel 1.

Karakteristik Subjek Penelitian

\begin{tabular}{|c|c|c|}
\hline Variabel & Frekuensi (orang) & Persentase (\%) \\
\hline \multicolumn{3}{|l|}{ Usia (tahun) } \\
\hline $25-34$ & 2 & 2,4 \\
\hline $35-44$ & 5 & 5,9 \\
\hline $45-54$ & 16 & 18,8 \\
\hline $55-64$ & 42 & 49,4 \\
\hline $65-74$ & 20 & 23,5 \\
\hline \multicolumn{3}{|l|}{ Jenis Kelamin } \\
\hline Laki-Laki & 22 & 25,9 \\
\hline Perempuan & 63 & 74,2 \\
\hline \multicolumn{3}{|l|}{ Status Perkawinan } \\
\hline Belum Menikah & 2 & 2,4 \\
\hline Menikah & 63 & 74,1 \\
\hline Cerai Mati & 20 & 23,5 \\
\hline \multicolumn{3}{|l|}{ Pendidikan (tahun) } \\
\hline 0 & 2 & 2,4 \\
\hline 6 & 27 & 31,8 \\
\hline 9 & 11 & 12,9 \\
\hline 12 & 21 & 24,7 \\
\hline$>12$ & 24 & 28,2 \\
\hline \multicolumn{3}{|l|}{ Pekerjaan } \\
\hline PNS & 7 & 8,2 \\
\hline Swasta & 4 & 4,7 \\
\hline Wiraswasta & 8 & 9,4 \\
\hline Pensiunan & 24 & 28,2 \\
\hline Ibu Rumah-Tangga & 42 & 49,4 \\
\hline \multicolumn{3}{|l|}{ Pendapatan } \\
\hline$\leq \mathrm{Rp} .1 .500 .000$ & 22 & 25,9 \\
\hline Rp 1.500 .000 s.d. 3.500 .000 & 62 & 72,9 \\
\hline$\geq \operatorname{Rp} 3.500 .000$ & 1 & 1,2 \\
\hline \multicolumn{3}{|l|}{ Aktivitas Fisik } \\
\hline$<600$ MET-min/minggu & 33 & 38,8 \\
\hline$\geq 600-<1500 \mathrm{MET}-\mathrm{min} / \mathrm{ming} g u$ & 42 & 49,4 \\
\hline$\geq 1500 \mathrm{MET}-\mathrm{min} / \mathrm{minggu}$ & 10 & 11,8 \\
\hline
\end{tabular}


Uji multivariat dilakukan pada enam variabel dengan memakai regresi path (pathreg) dengan menggunakan software Stata 12 (Tabel 5). Penelitian ini hanya memperoleh dua variabel yang berpengaruh pada kualitas diet, yaitu variabel pendapatan dan pendidikan. Selebihnya tidak didapatkan hubungan dan pengaruh yang signifikan antara variabel dukungan keluarga, pendidikan, pendapatan dan kualitas diet terhadap $\mathrm{HbA} 1 \mathrm{c}$. Terdapat faktor-faktor lain yang tidak diteliti dalam penelitian ini yang mungkin memiliki pengaruh langsung yang lebih besar pada nilai $\mathrm{HbA} 1 \mathrm{c}$, seperti aktivitas fisik, penggunaan obat-obatan, dan pemberian edukasi pada penderita DM (Bagan 1).

Tabel 2.

Profil Diabetes dan Status Gizi Subjek Penelitian

\begin{tabular}{|c|c|c|}
\hline Variabel & Frekuensi (orang) & Persentase (\%) \\
\hline \multicolumn{3}{|l|}{ Lama Menderita DM } \\
\hline $1-4$ & 33 & 38,8 \\
\hline $5-15$ & 42 & 49,4 \\
\hline$>15$ & 10 & 11,8 \\
\hline \multicolumn{3}{|l|}{ Jenis Pengobatan } \\
\hline Diet & 0 & 0 \\
\hline Obat Oral dan Diet & 54 & 63,5 \\
\hline Obat Suntik dan Diet & 12 & 17,7 \\
\hline Obat Oral, Suntik. dan Diet & 4 & 14,1 \\
\hline \multicolumn{3}{|l|}{ Jenis Komplikasi } \\
\hline Tidak Ada & 32 & 37,7 \\
\hline Retinopati & 14 & 16,5 \\
\hline Neuropati & 4 & 4,7 \\
\hline Penyakit jantung & 2 & 2,4 \\
\hline Luka pada kaki & 6 & 7,1 \\
\hline Stroke & 11 & 12,9 \\
\hline Hipertensi & 16 & 18,8 \\
\hline \multicolumn{3}{|l|}{ Frekuensi Edukasi Gizi } \\
\hline 0 & 4 & 4,7 \\
\hline 1 & 64 & 75,3 \\
\hline 2 & 17 & 20,0 \\
\hline \multicolumn{3}{|l|}{ IMT (kg/m²) } \\
\hline$<18,5$ & 1 & 1,2 \\
\hline $18,5-22,9$ & 60 & 70,6 \\
\hline $23-24,9$ & 18 & 21,2 \\
\hline $25-30$ & 6 & 7,1 \\
\hline \multicolumn{3}{|l|}{$\mathrm{HbA} 1 \mathrm{c}$} \\
\hline$\leq 6,5$ & 5 & 5,9 \\
\hline$\geq 6,5$ & 80 & 94,1 \\
\hline
\end{tabular}


Tabel 3.

Kualitas Diet Subjek Penelitian

\begin{tabular}{|c|c|c|c|}
\hline Komponen & Skor & Kriteria Skor & $(n=85)$ \\
\hline$\overline{\text { Total DQI-I }}$ & $0-100$ & & $55,97 \pm 6,1$ \\
\hline Variasi & $0-20$ & & $15,82 \pm 2,04$ \\
\hline Semua Variasi Makanan: & $0-15$ & $\begin{array}{l}\geq 1 \text { sajian dalam grup makanan } / \text { hari }=15 \\
1 \text { grup makanan tidak tersaji/hari }=12 \\
2 \text { grup makanan tidak tersaji/hari }=9 \\
3 \text { grup makanan tidak tersaji/hari }=6 \\
\geq 4 \text { grup makanan tidak tersaji/hari }=0\end{array}$ & $13,07 \pm 0,07$ \\
\hline $\begin{array}{l}\text { Variasi antar-grup untuk sumber } \\
\text { protein }\end{array}$ & $0-5$ & $\begin{array}{l}\geq 3 \text { sumber yang berbeda/hari }=5 ; 2 \text { sumber yang berbeda/hari }= \\
3 \text { dari } 1 \text { sumber protein } / \text { hari }=1 ; \text { tak ada sumber protein }=0\end{array}$ & $2,74 \pm 0,53$ \\
\hline Kecukupan & $0-30$ & & $23,91 \pm 3,77$ \\
\hline Grup serelia & $0-5$ & $\geq 6-11$ sajian $/$ hari $=5 ; 0$ sajian/hari $=0$ & $2,7 \pm 1,28$ \\
\hline Grup buah & $0-5$ & $\geq 2-4$ sajian/hari $=5 ; 0$ sajian $/$ hari $=0$ & $2,29 \pm 0,88$ \\
\hline Grup sayur & $0-5$ & $\geq 3-5$ sajian/hari $=5 ; 0$ sajian/hari $=0$ & $2,35 \pm 0,97$ \\
\hline Serat & $0-5$ & $\geq 20-30$ g/hari $=5 ; 0$ g/hari $=0$ & $2,07 \pm 0,61$ \\
\hline Protein & $0-5$ & $\geq 10 \%$ energi $/$ hari $=5 ; 0 \%$ energi $/$ hari $=0$ & $4,89 \pm 0,55$ \\
\hline Besi & $0-5$ & $\geq 100 \%$ Al/hari $=5 ; 0 \%$ Al/hari $=0$ & $3,48 \pm 1,06$ \\
\hline Calsium & $0-5$ & $\geq 10 \%$ Al/hari $=5 ; 0 \%$ Al/hari $=0$ & $2,96 \pm 1,05$ \\
\hline Vitamin C & $0-5$ & $\geq 100 \%$ AKG/hari $=5 ; 0 \%$ AKG/hari $=0$ & $3,14 \pm 1,05$ \\
\hline Ukuran & $0-30$ & & $13,90 \pm 2,57$ \\
\hline Total Lemak & $0-6$ & $\begin{array}{l}\leq 20 \% \text { dari total energi/hari }=6,>20-30 \% \text { dari total energi } / \text { hari }= \\
3,>30 \% \text { dari total energi/hari }=0\end{array}$ & $1,87 \pm 1,79$ \\
\hline Lemak Jenuh & $0-6$ & $\begin{array}{l}\leq 7 \% \text { dari total energi/hari }=6,>7-10 \% \text { dari total energi } / \text { hari }=3, \\
>10 \% \text { dari total energi/hari }=0\end{array}$ & $0,38 \pm 1,37$ \\
\hline Kolesterol & $0-6$ & $\leq 300 \mathrm{mg} / \mathrm{hari}=6,>300-400 \mathrm{mg} / \mathrm{hari}=3,>400 \mathrm{mg} / \mathrm{hari}=0$ & $4,91 \pm 1,89$ \\
\hline Natrium & $0-6$ & $\leq 2400 \mathrm{mg} / \mathrm{hari}=6,>2400-3400 \mathrm{mg} / \mathrm{hari}=3,>3400 \mathrm{mg} / \mathrm{hari}=0$ & $5,25 \pm 1,84$ \\
\hline Kalori dari gula/alkohol & $0-6$ & $\begin{array}{l}\leq 3 \% \text { dari total energi/hari }=6 \\
>3-10 \% \text { dari total energi } / \text { hari }=3 \\
>10 \% \text { dari total energi } / \text { hari }=0\end{array}$ & $0,45 \pm 1,35$ \\
\hline Keseimbangan Keseluruhan & $0-10$ & & $2,32 \pm 2,17$ \\
\hline Rasio makronutien (KH: $\mathrm{P}: \mathrm{L})$ & $0-6$ & $\begin{array}{l}55-65: 10-15: 15-25=6,52-68: 9-16: 13-27=4,50-70: 8-17: \\
12-30=2, \text { perbandingan lain }=0\end{array}$ & $2,25 \pm 0,65$ \\
\hline $\begin{array}{l}\text { Rasio asam lemak } \\
\text { (PUFA : MUFA : SFA) }\end{array}$ & $0-4$ & $\begin{array}{l}\mathrm{P} / \mathrm{S}=1-1,5 \text { dan } \mathrm{M} / \mathrm{S}=1-1,5=4 \text {, lainnya jika } \mathrm{P} / \mathrm{S}=0,8-1,7 \text { dan } \\
\mathrm{M} / \mathrm{S}=0,8-1,7=2, \text { perbandingan lain }=0\end{array}$ & $0,07 \pm 0,65$ \\
\hline
\end{tabular}

Tabel 4.

Dukungan Keluarga

\begin{tabular}{lcccc}
\hline Dukungan Keluarga & Rata-Rata & Standar Deviasi & Nilai Minimum & Nilai Maksimum \\
\hline Emosional & 2,86 & 0,41 & 1,80 & 3,70 \\
Penghargaan & 2,32 & 0,47 & 1,25 & 3,25 \\
Instrumental & 2,53 & 0,55 & 1,25 & 3,33 \\
Informasi & 2,39 & 0,46 & 1,37 & 3,50 \\
Total Skor & 2,52 & 0,45 & 1,46 & 3,36 \\
\hline
\end{tabular}

Tabel 5.

Prediksi Pengaruh Dukungan Keluarga, Pendapatan, dan Pendidikan terhadap Kualitas Diet

\begin{tabular}{lccc}
\hline Variabel & $\mathrm{B}$ & $\mathrm{t}$ & $\mathrm{p}$ \\
\hline Dukungan Keluarga & 0,12 & 1,10 & 0,273 \\
Pendapatan & $-0,27$ & $-2,29$ & 0,025 \\
Pendidikan & 0,28 & 2,34 & 0,022 \\
\hline
\end{tabular}




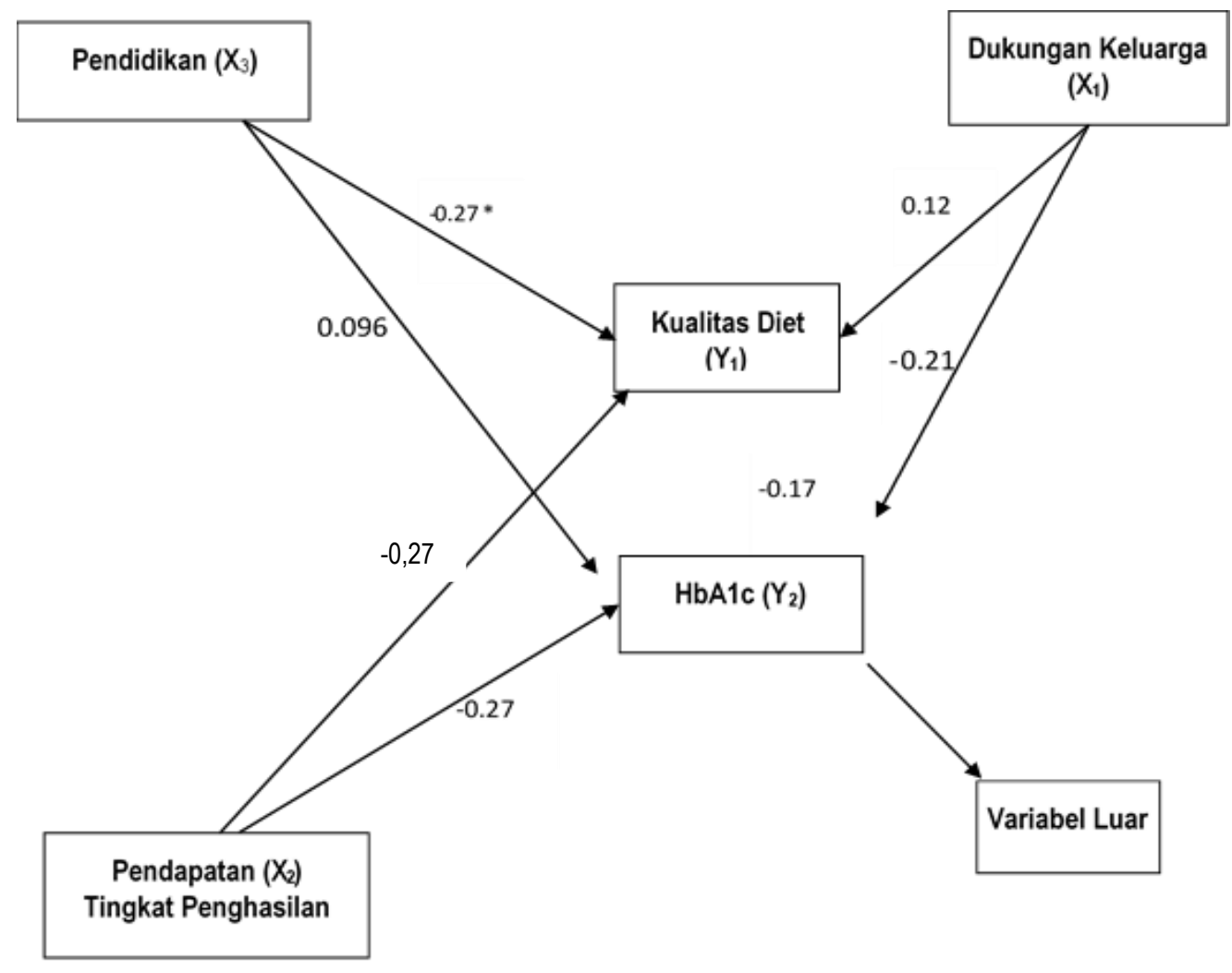

Gambar 1. Analisis dengan Metode Path Regression

\section{BAHASAN}

Sebanyak 49,4 persen subjek penelitian ini adalah ibu rumah-tangga, mendekati jumlah subjek pada penelitian di Iran, memperlihatkan prevalensi DM yang juga paling banyak dijumpai pada perempuan tidak bekerja (51\%). Hasil penelitian di Iran menunjukkan, kebanyakan perempuan tidak melakukan aktivitas fisik yang cukup karena adat dan kepercayaan yang mengharuskan mereka untuk tetap tinggal dalam rumah. ${ }^{13} \mathrm{lbu}$ rumah-tangga di Balikpapan yang berumur muda tak dibatasi secara khusus untuk tetap beraktivitas di luar rumah, tetapi karena dalam penelitian ini rata-rata ibu rumahtangga telah mencapai usia lanjut, aktivitas fisik berkurang karena keterbatasan umur. Hasil skoring dengan menggunakan IPAQ Score, seperti yang telah dilaporkan pada hasil penelitian di atas, hanya 11,8 persen subjek penelitian yang masih beraktivitas hingga mencapai $>1500 \mathrm{MET}$-menit/minggu. Rutinitas yang dikerjakan oleh pensiunan pada subjek penelitian laki-laki tidak jauh berbeda dengan rutinitas yang dikerjakan ibu rumah-tangga, yaitu lebih banyak melakukan sedentary activity, seperti menonton televisi, berbaring, membantu mengerjakan pekerjaan rumah-tangga ringan, seperti menyapu, menyiram bunga, dan hanya keluar rumah untuk mengikuti kegiatan rutin perkumpulan pensiunan.

Nilai Indeks Massa Tubuh (IMT) subjek paling banyak sekitar $18,5-22,9 \mathrm{~kg} / \mathrm{m}^{2}$. Hal ini menunjukkan bahwa kebanyakan subjek berstatus gizi normal. Semakin tinggi nilai IMT menunjukkan, seseorang mengalami kelebihan berat badan bila dibiarkan, maka terjadilah obesitas. Obesitas merupakan faktor penyebab resistensi insulin, yang terjadi akibat penurunan sensitivitas insulin. ${ }^{14}$ Obesitas perlu dihindari karena pasien DM obesitas memiliki risiko hiperglikemia lebih besar dibandingkan dengan pasien DM berstatus gizi normal. Ini yang menjadi dasar target tata laksana DM untuk mencapai status gizi normal. ${ }^{10}$ Rata-rata subjek penelitian hanya melakukan kunjungan edukasi gizi sebanyak satu kali $(75,3 \%)$. Hal tersebut dilakukan berdasarkan rujukan dokter. Pasien kurang memahami perlunya edukasi gizi, terutama untuk mengontrol konsumsi makanan. Sebuah studi Randomised Controlled Trial $(R C T)$ di California menunjukkan bahwa pasien DM memerlukan edukasi gizi dan edukasi manajemen diri sekaligus. Penelitian tersebut 
berhasil membuktikan hubungan yang signifikan antara pemberian kombinasi edukasi gizi dan manajemen diri pada pasien berusia lanjut. Edukasi yang diberikan berupa bagaimana mengartikan label gizi pada makanan, mengatur mekanisme diet yang tepat agar sesuai dengan penggunaan obat, perubahan pada pribadi dan motivasi untuk mengatur pola diet agar sesuai dengan anjuran..$^{15}$

Kualitas diet merupakan suatu parameter yang dapat menggambarkan asupan diet seseorang. Makin baik kualitas diet, maka semakin baik pula HbA1c pasien DM tipe $2 .{ }^{16}$ Peneliti melakukan pengkajian pada beberapa zat gizi penting yang secara teoretis memiliki pengaruh kuat terhadap kadar gula darah. Pertama adalah asupan karbohidrat; dalam penggunaan instrumen ini asupan karbohidrat dinilai berdasarkan perbandingan antara karbohidrat, protein, dan juga lemak. Hasil ratarata skor untuk penilaian ini adalah 2,25 dan rata-rata perbandingan ketiganya memberikan nilai yang baik. Namun, untuk asupan karbohidrat sederhana, dapat dilihat pada konsumsi empty calori food; rata-rata nilai yang diperoleh masih rendah, yakni 0,45. Berdasarkan pengisian Semi Questionnaire Food Frequency (SQ-FFQ) didapatkan hasil bahwa makanan yang dikonsumsi sering kali berupa kue basah, snack goreng dan makanan cepat saji dengan nilai empty calori food tinggi, yang membuat skor penilaian menjadi rendah.

Sebuah studi di Yunani yang menggunakan instrumen Healthy Eating Index (HEI) mendapatkan hasil, pasien DM dalam penelitian tersebut mengonsumsi karbohidrat berlebih bila dibandingkan dengan kontrol yang lebih banyak mengonsumsi sumber protein. Penelitian tersebut menemukan hubungan yang signifikan antara penggunaan skor kualitas diet dengan komplikasi DM. Kualitas diet rendah dijumpai pada pasien DM dengan gagal ginjal kronis. ${ }^{17}$

Rata-rata konsumsi protein yang diasup oleh subjek penelitian $>10$ persen; dalam pencapaian nilai skor sudah mendekati skor maksimal. Hal ini, bila dikategorikan, termasuk dalam kategori baik. Studi terbaru meyakini bahwa konsumsi tinggi protein lebih dianjurkan bagi penderita DM untuk mensubtitusi kalori dari karbohidrat. The Joslin's Weight Achievements and Intensive Treatment menyarankan untuk meningkatkan konsumsi protein sebesar 15-20 persen dari total kalori. Hasil riset yang telah dilakukan oleh pihak terkait melaporkan, terjadi penurunan berat badan $(p<0,001)$, penurunan lingkar pinggang $(p<0,001)$ dan penurunan kadar HbA1c $(p<0,001)$ pada pasien DM yang berhasil menjalankan diet sesuai dengan anjuran tersebut. 18 Berbeda dengan rekomendasi di atas, sebuah review yang dilakukan Nuttall dan Gannon menyebutkan, bahwa perlu diadakan pengkajian terhadap pencernaan protein kaitannya dengan proses metabolisme dalam tubuh, terutama bagi beberapa orang yang memiliki ketidakmampuan untuk beradaptasi dengan diet tinggi protein, sehubungan terdapat beberapa orang yang mengalami keseimbangan protein negatif setelah menerapkan diet tersebut. ${ }^{19}$ Skor total asupan lemak dalam penelitian ini rata-rata 1,85 , yang tergolong kurang baik karena jauh dari skor maksimal. Begitu juga dengan hasil perbandingan antara PUFA:MUFA dan SFA; hanya menghasilkan skor rata-rata 0,07 . Hal ini menandakan bahwa rata-rata asupan lemak dari subjek penelitian berlebih dengan kadar perbandingan antara lemak jenuh dan tidak jenuh yang juga kurang baik. Hasil penelitian yang dilakukan Harding et al. (2001) menunjukkan, terdapat hubungan yang signifikan antara asupan SFA dan $\mathrm{HbA} 1 \mathrm{c}$, tetapi tidak demikian dengan hasil analisis hubungan asupan MUFA. Penelitian tersebut berkesimpulan bahwa penurunan total asupan lemak dapat menurunkan kadar $\mathrm{HbA} 1 \mathrm{c}$ sebesar 0,0042 persen. ${ }^{20}$

Asupan serat dalam penelitian ini rata-rata hanya mencapai skor 2,05, sedangkan skor maksimumnya adalah 5. Rata-rata asupan sehari $15-16 \mathrm{~g}$, sedangkan nilai maksimum skor ini dapat dicapai jika asupan serat mencapai 25 $\mathrm{g} /$ hari. Negara maju telah mengembangkan diet Mediterania, terdiri dari makanan-makanan yang mengandung tinggi serat, kaya antioksidan dan sumber asam lemak tak jenuh. Diet tersebut dipercaya dapat memproteksi komplikasi jantung pada penderita DM. Namun, sejalan dengan penelitian ini, hubungan antara penerapan diet tersebut dengan perbaikan kadar glikemia dalam darah tidak signifikan. Penelitian berlanjut membandingkan konsumsi makanan rendah Indeks Glikemik (IG) dengan kadar HbA1c. Hasilnya menunjukkan, terdapat hubungan signifikan antara penurunan kadar $\mathrm{HbA} 1 \mathrm{C}$ dengan peningkatan konsumsi makanan yang mengandung $I G$ rendah. ${ }^{21}$ 
Pada penelitian ini, kualitas diet tidak mempengaruhi kadar $\mathrm{HbA} 1 \mathrm{c} \quad(p>0,05)$ dan belum terdapat subjek penelitian yang memiliki nilai total kualitas diet mencapai 75 . Padahal, skor tersebut menggambarkan tingkat mutu diet yang baik. Skor maksimum yang dapat dicapai hanya sebesar 70 . Sementara pada penelitian di Korea, dengan menggunakan 3 instrumen sekaligus (DQI, HDI dan HEI) pada 110 subjek penelitian, didapatkan korelasi yang tidak bermakna dengan $\mathrm{HbA} 1 \mathrm{c}$ pada pengukuran dengan instrumen $\mathrm{DQI}$ dan HEI. Namun, dengan Healthy Diet Index (HDI) didapatkan korelasi terbalik yang bermakna dengan $\mathrm{HbA} 1 \mathrm{c}$. Dalam penelitian tersebut Kim mengungkapkan kelemahan penelitian terletak pada penggunaan Food Recall 24-Hour yang tidak dapat menggambarkan kebiasaan makan subjek penelitian. ${ }^{12}$ Penelitian ini menggunakan SQFFQ yang disusun berdasarkan jenis makanan yang ada, disesuaikan dengan tempat penelitian. SQ-FFQ merupakan instrumen yang sangat baik untuk mengetahui pola makan subjek penelitian, sedangkan penilaian asupan hariannya merupakan rata-rata dari konsumsi selama satu bulan. Status sosio-ekonomi seseorang menentukan kesehatannya; sosioekonomi dinilai dari dua aspek, yaitu pendidikan dan pendapatan. Beberapa penelitian di Eropa mengaitkan antara status sosio-ekonomi seseorang dengan kemungkinan menderita penyakit kronis. Espelt et al. (2008), memuat penyataan Bron et al. (2008) dalam jurnalnya, menyebutkan bahwa keterkaitan tersebut dapat terjadi karena sosio-ekonomi yang baik dapat memenuhi faktor-faktor penunjang kesehatan, seperti ketersediaan makanan yang bersih dan sehat, tempat melakukan aktivitas kebugaran fisik, akses terhadap pelayanan kesehatan, dan ketersediaan obat yang diperlukan dalam proses penyembuhan penyakit. Khususnya pada pasien dengan DM adalah kemampuan untuk menyediakan fasilitas kontrol gula darah, seperti ketersediaan alat monitor gula darah dan obat-obatan pengendali gula darah. ${ }^{22}$

Penelitian yang dilakukan di 10 negara Eropa bagian Timur dan Barat, yang menghubungkan antara status sosio-ekonomi dengan morbiditas dan mortalitas DM, menunjukkan, ada hubungan bermakna, tetapi tidak berlaku pada semua negara. Hanya 3 negara yang menunjukkan hubungan yang signifikan yaitu di Norwegia, Belgia dan Italia. ${ }^{23}$
Pada analisis jalur tidak ditemukan adanya pengaruh pendidikan dan pendapatan dengan kadar HbA1c ( $p>0.05)$.

Sejalan dengan penelitian yang dilakukan Kurowska et al (2010), penelitian tersebut melihat hubungan antara level edukasi terhadap pekerjaan dan kaitannya dengan umur, durasi sakit DM dan kontrol HbA1c. Hasilnya hampir serupa dengan penelitian ini, setelah membandingkan level edukasi dan pekerjaan dengan $\mathrm{HbA} 1 \mathrm{C}$ didapatkan hasil yang tidak sejalan dengan teori yang ada. Pada penelitian tersebut didapatkan hasil bahwa subjek penelitian yang memiliki edukasi tinggi pekerjaan yang prestigius memiliki kadar $\mathrm{HbA} 1 \mathrm{c}$ yang buruk bila dibandingkan dengan kadar gula yang dimiliki oleh subjek penelitian yang memiliki edukasi standar dengan pekerjaan yang biasa-biasa saja. ${ }^{24}$ Peneliti memiliki pemikiran yang serupa dengan Kawakani et al (2000) yang menyatakan bahwa kurangnya kontrol HbA1c di tempat kerja semata-mata dipengaruhi oleh dukungan sosial ditempat kerja, tingkat stress pekerjaan dan waktu kurang untuk melakukan aktivitas fisik saat bekerja. ${ }^{12}$ Dukungan keluarga merupakan hal penting yang harus diterima oleh penderita DM sebagai salah satu upaya pemeliharaan gula darah. Dukungan tersebut berupa dukungan psikologis yang dibutuhkan untuk mencegah terjadinya stres pada penderita DM. Manajemen diri yang baik pada diri seorang penderita DM sangat tergantung dari dukungan keluarganya. ${ }^{8}$

Uji melalui analisis path regression terdapat hubungan yang tidak bermakna antara dukungan keluarga dengan $\mathrm{HbA} 1 \mathrm{C} \quad(\beta=0,21$ $p=0,058)$. Berbeda dengan sebuah penelitian di Iran mengenai dukungan keluarga yang dilihat hubungannya dengan kadar glikemia dalam tubuh. Penelitian ini dilakukan dengan melibatkan 430 sampel, 113 di antaranya merupakan penderita DM tipe 1 dan 317 merupakan penderita DM tipe 2. Pada penderita DM tipe 1 terdapat hubungan yang tidak bermakna, tetapi pada penderita DM tipe 2 terdapat hubungan yang bermakna $(p=0,01) .{ }^{25}$ Hal tersebut dapat terjadi karena perbandingan jumlah subjek penelitian antara penderita DM tipe 1 dan DM tipe 2 tidak sama. Sementara penelitian kami tidak menggunakan subjek yang menderita DM tipe 1.

Penelitian kami tidak sejalan dengan penelitian yang dilakukan oleh Epple et al. 
(2003), yang ketika diuji bivariat menemukan, ada hubungan yang signifikan antara dukungan keluarga dengan kadar $\mathrm{HbA1c}(p<0,05)$. Pada penelitian tersebut dilibatkan 234 subjek penelitian, kemudian kuesioner yang disebar berisi pertanyaan tentang bentuk dukungan keluarga, seperti siapa yang memasak makanan di rumah, jenis bahan apa yang biasa dikonsumsi, bagaimana peran suami/istri dalam memasak dan menyajikan makanan. Selain melihat hubungan antara dukungan keluarga dengan $\mathrm{HbA} 1 \mathrm{C}$, penelitian ini juga melihat hubungan antara dukungan keluarga dengan kadar kolesterol dan trigliserida. ${ }^{23}$ Sejalan dengan penelitian tersebut, sebuah penelitian di Jepang menunjukkan adanya hubungan bermakna antara dukungan keluarga dengan penurunan $\mathrm{HbA} 1 \mathrm{c}$. Penelitian ini melibatkan 112 orang dengan usia di atas 60 tahun. Dukungan keluarga dalam penelitian ini dikaitkan pula dengan kadar trigliserida. ${ }^{26}$ Hasil uji yang didapatkan pada penelitian ini sejalan dengan hasil penelitian RCT yang dilakukan Eakin (2013). Pada penelitian tersebut didapatkan hasil bahwa dengan uji multivariat tidak ditemukan adanya pengaruh dukungan keluarga terhadap kadar HbA1c. Pada penelitian tersebut disimpulkan bahwa selain dukungan keluarga, terdapat faktor lain yang lebih berperan, yaitu aktivitas fisik, perubahan kebiasaan makan dan target untuk menurunkan berat badan. ${ }^{27}$

Dukungan keluarga didapatkan oleh penderita DM melalui keempat aspek, yaitu dimensi emosional, instrumental, penghargaan, dan informasi baik untuk ditingkatkan karena makin tinggi dukungan tersebut, semakin baik kondisi pasien dalam menghadapi penyakit, terutama dari segi psikologis. Ada beberapa faktor lain yang tidak ikut diteliti dalam penelitian ini. Namun, secara teoretis memiliki pengaruh terhadap kadar HbA1c. Beberapa faktor, seperti usia, jenis kelamin dan aktivitas fisik, telah dibahas pada subbab sebelumnya. Salah satu variabel yang tidak diteliti pada penelitian ini adalah penggunaan obat-obatan.

Penggunaan obat-obatan memiliki peran yang besar terhadap pengendalian gula darah. Jenis obat-obatan membedakan cara kerja dan efek yang dihasilkan pada kontrol gula darah. Pada penelitian ini sebesar 63,53 persen subjek penelitian menggunakan obat oral. Berdasarkan hasil wawancara rata-rata pasien menggunakan metformin dan glibenklamid. Sementara sebesar 17,7 persen subjek penelitian telah menggunakan obat injeksi. Metformin merupakan salah satu anti-hiperglikemia efektif dan memiliki efek kardioprotektif. Namun, dalam penggunaannya masih terdapat kontra-indikasi. Metformin sebagai insulin sensitizer bekerja melalui efek utamanya pada penekanan produksi gula hepar, meningkatkan ambilan glukosa di jaringan lemak, otot dan berbagai pleiotrofik. Kontra-indikasi metformin berdasarkan keterangan beberapa pabrik farmasi, antara lain gangguan fungsi ginjal, gagal jantung, gagal respirasi, gangguan berat fungsi hepar, hipoksia jaringan, penyakit kekurusan, dan kegawatan akut DM..$^{28}$ Penelitian meta-analisis yang dilakukan untuk menguji apakah penggunaan metformin aman, mendapatkan data bahwa pengujian 8 subklas metformin dapat menurunkan kadar $\mathrm{HbA} 1 \mathrm{c}$ secara signifikan. ${ }^{29}$

Penelitian mengenai penggunaan obat lainnya yang dilakukan dengan sistem metaanalisis RCT menemukan efek penurunan kadar $\mathrm{HbA} 1 \mathrm{C}$ pada penggunaan obat oral di antaranya biguanid, sulfonilurea, DPP4inhibitor, TZDs dan Meglitinide. Dari penelitian tersebut didapatkan hasil bahwa makin rendah penggunaan terapi obat, maka kadar $\mathrm{HbA} 1 \mathrm{c}$ semakin tinggi. Penurunan kadar $\mathrm{HbA} 1 \mathrm{c}$ sebesar 1-1,25 persen didapatkan dalam penggunaan obat selama 3-6 bulan, khususnya dari jenis sulfonilurea dan TZDs. ${ }^{29}$ Penggunaan injeksi insulin diterapkan pada penderita DM kronis, yang telah memiliki kerusakan pankreas lebih lanjut. Penggunaan injeksi insulin terbukti mampu memelihara dan menjaga kestabilan gula darah. Pilihan kombinasi obat diberikan apabila keadaan DM sudah cukup berat. Terapi insulin diberikan karena dengan adanya terapi ini menimbulkan efek anabolik yang memberikan rasa segar. ${ }^{30}$

Salah satu faktor lain yang dapat meningkatkan kadar $\mathrm{HbA} 1 \mathrm{c}$ adalah terjadinya infeksi. Penelitian di Inggris menyebutkan bakteri Helicobacter pylori (H. pylori) dapat mengakibatkan terjadinya peningkatan $\mathrm{HbA} 1 \mathrm{C}$. $H$. pylori merupakan bakteri yang hidup di lambung. Bakteri tersebut dapat mengakibatkan inflamasi yang menyebabkan terjadinya produksi $\mathrm{HbA} 1 \mathrm{c}$ berlebih karena terganggunya homeostasis leptin. Sebuah studi populasi yang dilakukan National Health Nutrition and 
Eximination Survey (NHANES) sejak tahun 1999-2000 menyebutkan adanya hubungan yang signifikan antara terjadinya peningkatan level $\mathrm{HbA} 1 \mathrm{c}$ pada subjek yang mengalami infeksi $H$. pylori $(p<0,01) .{ }^{31}$ Penelitian terkini di China menunjukkan, subjek penelitian yang memiliki infeksi $H$. pylori memiliki HbA1c lebih tingggi dibandingkan subjek DM yang tidak terinfeksi bakteri tersebut $(p=0,009) .{ }^{32}$

\section{SIMPULAN DAN SARAN}

\section{Simpulan}

Kualitas diet subjek penelitian rata-rata mencapai kualitas sedang. Subjek penelitian sering mendapatkan dukungan keluarga dari dimensi emosional dan instrumental. Namun, jarang menerima dukungan keluarga dari dimensi penghargaan dan informasi. Terdapat hubungan yang bermakna antara pendidikan dan pendapatan dengan kualitas diet. Namun, tidak ditemukan hubungan yang bermakna antara kualitas diet, pendapatan dan pendidikan dengan kadar $\mathrm{HbA} 1 \mathrm{C}$.

\section{Saran}

Keluarga pasien DM perlu ikut serta ketika pasien menerima edukasi manajemen DM dan edukasi gizi, sehingga dapat meningkatkan dukungan keluarga dari segi informasi dan dimensi penghargaan. Perlu dilakukan penelitian lebih lanjut untuk meneliti variabel luar yang tidak diteliti dalam penelitian ini.

\section{UCAPAN TERIMA KASIH}

Staf humas, staf ahli gizi, staf Unit Rawat Jalan Poli Interna dan Staf Laboratorium RSKD Balikpapan, yang telah sangat membantu dalam pengambilan data penelitian ini, serta pasien DM Tipe 2 Unit Rawat Jalan Poli Interna RSKD Balikpapan yang telah bersedia berpartisipasi dalam penelitian ini.

\section{RUJUKAN}

1. Sizer FS, Whitney E. The Carbohydrates: Sugar, Starch, Glycogen, and Fiber. In: Nutrition: Concepts and Controversies, 10 th Edition. Belmont: Wadsworth, 2006. p. 121-123.

2. Indonesia, Departemen Kesehatan. Jaminan Kesehatan Nasional. Jakarta: Depkes RI, 2012.

3. Kim S, Haines PS, Siega-Riz AM, Popkin BM. The Diet Quality Index-International (DQI-I) provides an effective tool for cross-national comparison of diet quality as illustrated by China and the United States. J. Nutr. 2003; 133(11): 3476-84.

4. Veghari $G$, Sedaghat $M$, Joshaghani $H$, Hoseini SA, Niknezad F, Angizeh A, Tazik E, Moharloei P. Association between socio-demographic factors and diabetes mellitus in the north of Iran: A population-based study. Int $\mathrm{J}$ Diabetes Mellit. 2010; 2(3): 154-7.

5. Mihardja L. Faktor yang berhubungan dengan pengendalian gula darah pada penderita diabetes mellitus di perkotaan Indonesia. Maj Kedokt Indon. 2009; 59(9): 418-24.

6. Yun J-O, Kim K-N. Relationships of family support, dietary theraphy practice and blood glucose control in type II diabetic patients. Nutr $\begin{array}{llll}\text { Res Pract. } 2009 & 3(2): & 141-8 & \text { Doi: }\end{array}$ 10.4162/nrp.2009.3.2.141.

7. Lemeshow S, Hosmer Jr DW, Klar J, Lwanga SK. Besar Sampel dalam Penelitian Kesehatan. Terjemahan Pramono D. Yogyakarta: Gadjah Mada University Press, 1997.

8. Hensarling JB. Development and psychometric testing of Hensarling's diabetes family support scale. Dissertation. Texas: Texas Woman's University, 2009.

9. Muhidin SA, Abdurahman M. Analisis Korelasi, Regresi dan Jalur dalam Penelitian. Bandung: Pustaka Setia, 2009.

10. Rudijanto A, Yuwono A, Shahab A, Manaf A, Promono $B$, Lindarto $D$, et al. Konsensus Pengelolaan dan Pencegahan Diabetes Melitus Tipe 2 di Indonesia 2015. Jakarta: Pengurus Besar Perkumpulan Endokrinologi Indonesia (PB Perkeni), 2015.

11.Syam K. Hubungan Pola Konsumsi Makanan dengan Kejadian Diabetes Melitus Tipe 2 pada Penduduk Wanita di Kota Banjarmasin. Tesis. Yogayakarta: Fakultas Kedokteran Universitas Gadjah Mada, 2012.

12. Kim JY, Cho YY, Park YM, Sohn CM, Rha MY, Lee MK, et al. Association of dietary quality indices with glycemic status in Korean patients with type 2 diabetes. Clin Nutr Res. 2013; 2(2): 100-6.

13. Innocent O, ThankGod OO, Sandra EO, Josiah IE. Correlation between body mass index and blood glucose levels among some Nigerian undergraduates. HOAJ Biology 2013.

14. Miller CK, Edwards L, Kissling G, Sanville L. Nutrition education improves metabolic outcomes among older adults with diabetes mellitus: results from a randomized controlled trial. Prev Med. 2002; 34(2): 252-9.

15. Murray AE, McMorrow AM, O'Connor E, Kiely C, Mac Ananey O, O'Shea D, et al. Dietary quality in a sample of adults with type 2 diabetes mellitus in 
Ireland: a cross-secsional case control study. Nutr J. 2013; 12: 110.

16. Mangou A, Grammatikopoulou MG, Mirkopoulou D, Sailer N, Kotzamanidis C, Tsigga M. Associations between diet quality, health status and diabetic complications in patiens with type 2 diabetes and comorbid obesity. Endocrinol Nutr. 2012; 59(2): 109-16.

17. Hamdy O, Horton ES. Protein content in diabetes nutrition plan. Curr Diab Rep. 2011; 11(2):111-9.

18. Nuttall FQ, Gannon MC. 2013, Dietary protein and the blood glucose concentration. Diabetes. 2013; 62(5): 1371-2.

19. Harding AH, Sargeant LA, Welch A, Oakes S, Luben RN, Bingham $S$, et al. Fat consumption and HbA1c levels: the EPIC-Norfolk study. Diabetes Care. 2001; 24(11): 1911-6.

20. Ben-Avraham S, Harman-Boehm I, Schwarzfuchs D, Shai I. Dietary strategies for patients with type 2 diabetes in the era of multi-approaches: review and results form the Dietary Intervention Randomized Controlled Trial (DIRECT). Diabetes Res Clin Pract. 2009, 86 Suppl 1: S41-8.

21. Espelt A, Borrel C, Roskam AJ, Rodriguez-Sanz M, Stirbu I, Dalmau-Bueno A, et al. Socioeconomic inequalities in diabetes mellitus across Europe at the beginning of the $21^{\text {st }}$ century. Diabetologia. 2008; 51(11): 1971-9.

22. Epple C, Wright AL, Joish VN, Bauer M. The role of active family nutritional support in Navajos' type 2 diabetes metabolic control. Diabetes Care. 2003; 26(10): 2829-34.

23. Kurowska M, Tarach JS, Malicka J, Dabrowska A. The impact of employment and the level of personal education on $\mathrm{HbA} 1 \mathrm{c}$ concentrations in patiens with type 2 diabetes. Diabet Dośw Klin. 2010; 10: 2: 86-90.

24. Tol A, Baghbanian A, Rahimi A, Shojaeizadeh D, Mohebbi B, Majlessi F. The relationship between perceived social support from family and diabetes control among patients with diabetes type 1 and type 2. J Diabetes Metab Disord. 2011; 10: 1-8.

25. Watanabe K, Kurose T, Kitatani N, Yabe D, Hishizawa M, Hyo T, et al. The role of family nutritional support in Japanese patients with type 2 diabetes mellitus. Intern Med. 2010; 49(11): 983-9.

26. Eakin EG, Reeves MM, Winkler E, Healy GN, Dunstan DW, Owen N, et al. Six-month outcomes from living well with diabetes: A randomized trial of telephone-delivered weight loss and physical activity intervention to improve glycemic control. Ann Behav Med. 2013; 46(2): 193-203.

27. Nugroho, Djokomoeljanto. Kontroversi Metformin. Dalam: Naskah Lengkap Diabetes Melitus Ditinjau dari Berbagai Aspek Penyakit Dalam. Semarang: Badan Penerbit Universitas Diponegoro, 2007.
28. DeFronzo RA, Stonehouse AH, Han J, Wintle ME. Relationship of baseline HbA1c and efficacy of current glucose-lowering therapies: a metaanalysis of randomized clinical trials. Abstract. Diabet Med. 2010; 27(3): 309-17.

29. Sherifali D, Nerenberg K, Pullenayegum E, Cheng JE, Gerstein HC. The effect of oral antidiabetic agents on A1C levels. Diabetes Care. 2010; 33(8): 1859-64.

30. Effendi AT, Waspadji S. Terapi Gizi Medik. Dalam: Aspek Biomolekuler Diabetes Melitus II. Jakarta: Badan Penerbit Fakultas Kedokteran Universitas Indonesia, 2011.

31. Brown T. Helicobacter pylori infection may increase hemoglobin A1c levels. Clin Med Edu. 2012; 21: 13.

32. Hsieh MC, Wang SS, Hsieh YT, Kuo FC, Soon MS, Wu DC. Helicobacter pylori infection association with high $\mathrm{HbA} 1 \mathrm{c}$ and type 2 diabetes. Abstract. Eur J Clin Invest. 2013; 43(9): 949-56. 